\title{
Retrograde Intrarenal Surgery or Shock Wave Lithotripsy?: Comparison of the Effects on Renal Functions by Glomerular Filtration Rate
}

\author{
Retrograd Intrarenal Cerrahi veya Şok Dalga Litotripsi?: Renal Fonksiyonlar Üzerindeki \\ Etkilerinin Glomerüler Filtrasyon Hızı ile Karşılaştııılması
}

\author{
(1) Selçuk Sarıkaya1', (1) Nejdet Karşıyakalı2, (1) Can Sicimli1, (1) Engin Kaya1, (1) Turgay Ebiloğlu¹, (1) Selahattin Bedir1, \\ (1) Taner Özgürtaş3, (1) Ömer Faruk Karataş1 \\ 1 University of Health Sciences, Gülhane Training and Research Hospital, Clinic of Urology, Ankara, Turkiye \\ ${ }^{2}$ Çukurca State Hospital, Clinic of Urology, Hakkari, Turkiye \\ 3 University of Health Sciences, Gülhane Training and Research Hospital, Clinic of Biochemistry, Ankara, Turkiye
}

What's known on the subject? and What does the study add?

In this paper, we showed that there is a significant glomerular filtration rate decrease after retrograde intrarenal surgery when compared with schok wave lithoripsy (SWL) especially the stones with a diameter of less than $20 \mathrm{~mm}$ in both of early and late post-operative period. This is significant because we believe that our study will have an important place in the literature because best of our knowledge this is the first research in the literature which one compares the renal functional outcomes after RIRS and SWL.

\begin{abstract}
Objective: In this study, we aimed to evaluate and compare the effects of retrograde intrarenal surgery (RIRS) and schok wave lithoripsy (SWL) interventions on renal functions by analyzing glomerular filtration rate (GFR) values.

Materials and Methods: A total of 95 patients, who underwent RIRS or SWL in 2017 at Gülhane Training and Research Hospital, were included in this retrospective study. Forty-six of these patients (48.4\%) were in RIRS group and 49 (51.6\%) were in SWL group. Preoperative, early-postoperative (on the first postoperative day) and late-postoperative (on the first postoperative month) GFR values were calculated using the "abbreviated Modification of Diet in Renal Disease" Method. Changes in GFR values after RIRS and SWL treatments were compared statistically.

Results: When the early postoperative and late postoperative GFR levels were compared, a statistically significant difference was observed between the groups ( $p=0.04$ and $p<0.001$, respectively). For RIRS group, there was a $0.37 \pm 13.5 \mathrm{~mL} / \mathrm{min} / 1.73 \mathrm{~m}^{2}$ increase and for SWL group, there was $5.65 \pm 12.5 \mathrm{~mL} / \mathrm{min} / 1.73 \mathrm{~m}^{2}$ increase in GFR values in the early postoperative period. There was a $2.40 \pm 14.1 \mathrm{~mL} / \mathrm{min} / 1.73 \mathrm{~m} 2 \mathrm{decrease}$ in RIRS group and $7.75 \pm 11.8 \mathrm{~mL} / \mathrm{min} / 1.73 \mathrm{~m}^{2}$ increase in SWL group in GFR values in the late postoperative period. In general linear model, there was a statistically significant difference in changes in GFR over time between RIRS and SWL groups ( $p=0.002)$. There was also a statistically significant difference when the changes in GFR over time were compared according to stone locations ( $p=0.02)$.

Conclusion: RIRS is associated with less improved GFR in comparison with SWL. SWL should be considered as first line treatment for kidney and ureteral stones when considering the changes in GFR values comparing to RIRS especially for stones smaller than $20 \mathrm{~mm}$.

Keywords: Glomerular filtration rate (GFR), Modification of Diet in Renal Disease (MDRD), Renal function, Retrograde intrarenal surgery (RIRS), Shock wave lithotripsy (SWL), Urolithiasis
\end{abstract}

Öz

Amaç: Bu çalışmada, retrograd intrarenal cerrahi (RIRS) ve şok dalgası litotripsi (SWL) işlemlerinin renal fonksiyonlar üzerindeki etkisini glomerüler filtrasyon hızı ölçümü (GFR) ile değerlendirmeyi ve karşılaştırmayı amaçladık.

Gereç ve Yöntem: 2017 yılında Gülhane Eğitim ve Araştırma Hastanesi'nde RIRS veya SWL işlemi uygulanan toplamda 95 hasta bu retrospektif çalışmaya dahil edildi. Hastaların 46'sı $(\% 48,4)$ RIRS, 49'u ise $(\% 51,6)$ SWL grubundaydı. Operasyon öncesi, operasyon sonrası erken dönem (post-op

Correspondence: Nejdet Karşıyakalı MD, Çukurca State Hospital, Clinic of Urology, Hakkari, Turkiye

Phone: +90 5058652463 E-mail: nkarsiyakali@hotmail.com ORCID-ID: orcid.org/0000-0002-0709-0331

Received: 19.08.2019

Accepted: 14.09 .2019

Cite this article as: Sarıkaya S, Karşıyakalı N, Sicimli C, Kaya E, Ebiloğlu T, Bedir S, Özgürtaş T, Karataş ÖF. Retrograde Intrarenal Surgery or Shock Wave Lithotripsy?: Comparison of the Effects on Renal Functions by Glomerular Filtration Rate. J Urol Surg 2019;6(4):295-301.

๑Copyright 2019 by the Association of Urological Surgery / Journal of Urological Surgery published by Galenos Publishing House. 
1. gün) ve geç dönem (post-op 1. ay) GFR değerleri "abbreviated Modification of Diet in Renal Disease" yöntemi ile hesaplandı. RIRS ve SWL tedavisi sonrasındaki GFR düzeyindeki değişimler istatistiksel olarak karşılaştırıldı.

Bulgular: Erken post-operatif ve geç post-operatif GFR düzeyleri karşılaştırılığında gruplar arasında istatistiksel anlamlı farklılığın olduğu izlendi

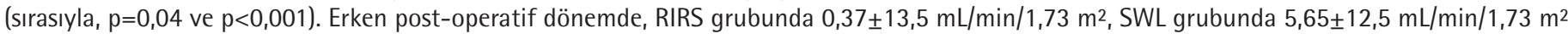
GFR düzeyinde artış olduğu izlendi. Geç post-operatif dönem GFR düzeylerinde, RIRS grubunda $-2,40 \pm 14,1 \mathrm{~mL} / \mathrm{min} / 1,73 \mathrm{~m}{ }^{2} \mathrm{düşüş,} \mathrm{SWL} \mathrm{grubunda}$ ise 7,75 $\pm 11,8 \mathrm{~mL} / \mathrm{min} / 1,73 \mathrm{~m}^{2}$ artış olduğu izlendi. Zamanla GFR değişiminin değerlendirildiği genel lineer model analizinde RIRS ve SWL grupları arasında istatistiksel farklılık olduğu izlendi $(p=0,002)$. Ayrıca hastaların zamanla GFR değişimleri karşılaştırıldığında taş lokalizasyonuna göre de istatistiksel anlamlılık elde edildi $(p=0,02)$.

Sonuç: RIRS, SWL ile karşılaştırıldığında daha az düzelmiş GFR ile ilişkilidir. Özellikle çapı 20 mm'den daha küçük olan böbrek ve üreter taşlarında, GFR düzeylerindeki değişimler göz önüne alındığında SWL birincil tedavi seçeneği olarak düşünülmelidir.

Anahtar Kelimeler: Glomerüler filtrasyon hızı, Modification of Diet in Renal Disease, Renal fonksiyon, Retrograd intrarenal cerrahi, Şok dalga litotripsi, Ürolitiyazis

\section{Introduction}

Urolithiasis is a common health problem with increasing incidence. The prevalence of urolithiasis is approximately $2-3 \%$ in the general population. Urolithiasis have a high recurrence rate and approximately $50 \%$ of patients with previous urinary stones have recurrence within 10 years $(1,2,3)$. Kidney stones may lead to renal colic, haematuria, pyelonephritis and renal failure or decreased function (2). Treatment methods mainly depend on the size and the location of the stone $(4,5,6)$. Stone characteristics, experience of the surgeon and availability of the equipment are determining factors in selecting the optimum treatment method (7). At present, minimally invasive treatment options are the first choice for most of urinary system stones with the advances in endourology. Kidney stones with a diameter of less than $20 \mathrm{~mm}$ are mainly treated with shock wave lithotripsy (SWL), retrograde intrarenal surgery (RIRS) and percutaneous nephrolithotomy (PCNL) (4). SWL is a highly preferred, safe and non-invasive method used to treat urinary stone disease (8). SWL was also defined as a treatment modality with minimal morbidity and simplicity (7). However, the treatment cycles and efficacy in lower calyceal renal calculi are still uncertain (9).

It is known that stone removal can improve renal function, however, procedures may negatively affect the renal parenchyma (10). SWL can result in renal parenchymal damage and impaired renal function (11).

Renal function can be calculated using several methods. Glomerular filtration rate (GFR) is the most commonly used measurement of renal function. Cockroft-gault formula, Modification of Diet in Renal Disease (MDRD) and chronic kidney disease epidemiology collaboration equations are the common methods for calculating GFR (12). After the first definition of the MDRD study equation, the formula abbreviated MDRD (aMDRD) was developed to facilitate clinical use (13).

In this study, we aimed to evaluate and compare the effects of RIRS and SWL interventions on renal functions by evaluating GFR values using the aMDRD formula.

\section{Materials and Methods}

The patients who underwent RIRS or SWL in 2017 at Gülhane Training and Research Hospital were included in this retrospective study. All patients were evaluated with unenhanced computed tomography (CT) before interventions. The patients were informed about RIRS and SWL procedures. RIRS was offered as primary treatment option to patients who have stones greater than $20 \mathrm{~mm}$ and SWL was offered as primary treatment option to patients who have stones less than $20 \mathrm{~mm}$ in diameter. The patients were included in the groups according to their treatment preferences. Patients unresponsive to SWL treatment and those scheduled for endoscopic surgery were excluded from the study. The study was conducted in accordance with the principles of the Declaration of Helsinki. Demographic data, perioperative, operative, postoperative results and GFR values were evaluated in detail. GFR values were calculated with the aMDRD formula as previously described: $186 \times$ serum creatinine $\mathrm{e}^{-1,154} \mathrm{xage}^{-0,203}$ ( $\mathrm{x} 0.742$ if female), (x1.210 if black) (13). Preoperative, early postoperative (on the first postoperative day) and late postoperative (on the first postoperative month) GFR values were noted, and also the differences between these values were recorded and compared between the two groups.

\section{Surgical Procedure}

All patients were administered prophylactic single dose intravenous antibiotic (cefazolin sodium 1 gram) before the operation. Operations were performed under general anesthesia. Patients were placed in the semi-lithotomy position according to direction of the stone on the surgical table which fluoroscopy device can be used. Operations were started with semi-rigid URS, a 0.038-inch polytetrafluoroethylene-coated safety guidewire was sent to the upper urinary system under visual and fluoroscopic control. An appropriate ureteral access sheath (10/12-Fr or 12/14-Fr, Re-trace Ureteral Access Sheath, Coloplast, Humlebaek, Denmark) was inserted through the safety guidewire under fluoroscopy control. In all cases, a 7.5- $\mathrm{Fr}$ flexible URS device (Karl Storz Endoskope, FLEX-X², Tuttlingen, 
Germany) was used. The holmium: YAG laser fiber with a diameter of 270- $\mu \mathrm{m}$ or 365- $\mu \mathrm{m}$ was used for crushing the stone. Laser energy was kept between 0.6 and $0.8 \mathrm{~J}$, the frequency was kept between 8 and 10 Hertz. The operation was terminated by verifying that no opacity was observed under fluoroscopy control. A 4.8 Fr double-J stent was inserted in all the patients at the end of the operation.

\section{SWL Procedure}

SWL was performed on the basis of a scheduled treatment program via an electromagnetic lithotriptor (Siemens ${ }^{\circledR}$ Lithoskop, Erlangen Germany) by one single experienced technician after administration of intramuscular analgesic (Diclofenac Sodium $75 \mathrm{mg}$ ) just half an hour before the SWL session. Repeat SWL sessions were performed for stones showing fragmentation until clinically insignificant residual fragment or stone-free status was achieved. The interval between SWL sessions was 3 days for ureter stones and 7 days for kidney stones. A maximum of 3 SWL treatments were performed.

\section{Stone-free Status and Follow-up}

Stone-free status was defined as no stone on control unenhanced CT scan. Stones less than $3 \mathrm{~mm}$ in diameter on unenhanced CT images were considered clinically insignificant fragments. Ureteral I stents were removed under local anesthesia approximately 2-3 weeks after the surgery.

\section{Statistical Analysis}

Statistical analysis was performed using SPSS 22.0 package program. Descriptive data were presented as mean and standard deviation. The normal distribution of the quantitative data was analyzed using the Kolmogorov-Smirnov test and graphical representations. The independent samples t-test was used to compare two groups of quantitative variables showing normal distribution and the Mann-Whitney $\mathrm{U}$ test and Wilcoxon signed rank test were used to compare two groups of quantitative variables that did not show normal distribution. Stone sizes and changes in GFR value in the early post-operative and late post-operative periods were compared between the groups and the same variables were compared between patients who were subgrouped according to stone location using the Mann-Whitney U test. Pre-operative, early post-operative and late post-operative GFR values were compared using the independent samples t-test. ANOVA test was used to compare preoperative, early and late postoperative GFR values between the groups. General linear model was used in repeated measures for evaluating the association between GFR changes over time between RIRS and SWL groups and between patients who were subgrouped according to stone location. Post-hoc analyses were performed with Bonferroni test for pairwise comparisons. A $p$ value of less than 0.05 was considered statistically significant.

\section{Results}

A total of 95 patients were included in the study. Forty-six of these patients (48.4\%) were in RIRS group and 49 (51.6\%) were in SWL group. The mean age of the patients was $45.1 \pm 14.8$ years (20-78). Thirty-two patients (33.7\%) were female and 63 $(66.3 \%)$ were male. The mean stone size was $16.3 \pm 7.5 \mathrm{~mm}$ and $11.0 \pm 4.0 \mathrm{~mm}$ in the RIRS and SWL groups, respectively. Fortyseven patients $(49.4 \%)$ had stones located in the right kidney and ureters. Forty-eight patients (50.6\%) had in the left side. Demographic characteristics and operative features of each group are summarized in Table 1. Stone size was compared between the groups. There was a statistically significant difference in the mean stone size between the two groups $(p<0.001)$ (Table 1).

There were no statistical differences in preoperative, early postoperative and late postoperative GFR values between the groups ( $p>0.05$ ). There was a statistically significant difference between the groups in terms of the differences between preoperative and early postoperative and preoperative and late postoperative GFR values ( $p=0.04$ and $p<0.001$, respectively).

Mean differences were evaluated in the early and late postoperative periods. In the early postoperative period, there was a mean increase of $0.37 \pm 13.5 \mathrm{~mL} / \mathrm{min} / 1.73 \mathrm{~m}^{2}$ and $5.65 \pm 12.5 \mathrm{~mL} / \mathrm{min} / 1.73 \mathrm{~m}^{2}$ in GFR values in RIRS and SWL groups, respectively. In the late postoperative period, there was a mean decrease of $2.40 \pm 14.1 \mathrm{~mL} / \mathrm{min} / 1.73 \mathrm{~m}^{2}$ and a mean increase of $7.75 \pm 11.8 \mathrm{~mL} / \mathrm{min} / 1.73 \mathrm{~m}^{2}$ in GFR values in RIRS and SWL groups, respectively. There were statistically significant differences in early and late changes in GFR between the groups $(p=0.04$ and $p<0.001$, respectively) (Table 1$)$. When the patients were compared according to gender, there was no difference in GFR change in the early and late postoperative periods ( $p>0.05$ for both).

There was a statistically significant difference in changes in GFR over time between RIRS and SWL groups $(p=0.002)$. Both early and late postoperative GFR values were higher in the SWL group (Figure 1). There was also a statistically significant difference when the changes in GFR over time were compared according to stone location $(p=0.02)$. In post-hoc analysis, it was observed that the increase in GFR in the late postoperative period was statistically significantly higher in patients with ureter stones than in those with stones in the lower pole and middle pole $(p=0.001$ and $p<0.001$, respectively).

RIRS and SWL groups were matched for stone locations and compared for stone size and GFR value. Stone size was statistically larger in patients who underwent RIRS for middle pole kidney stones that in those SWL was performed for middle pole kidney stones $(p=0.03)$. There was no statistically significant 
Table 1. Demographics and operative features of patients

\begin{tabular}{|c|c|c|c|c|}
\hline & & \multicolumn{2}{|l|}{ Group } & \multirow{2}{*}{ p-value } \\
\hline & & $\begin{array}{l}\text { RIRS }(n=46) \\
n(\%)\end{array}$ & $\begin{array}{l}\text { SWL }(n=49) \\
n(\%)\end{array}$ & \\
\hline \multirow{2}{*}{ Gender } & Female & $12(26.1 \%)$ & $20(40.8 \%)$ & \multirow[b]{2}{*}{${ }^{\mathrm{b}} 0.129$} \\
\hline & Male & $34(73.9 \%)$ & $29(59.2 \%)$ & \\
\hline Side & Left & $23(50 \%)$ & $25(51.0 \%)$ & ${ }^{\mathrm{b}} 0.92$ \\
\hline \multirow{4}{*}{$\begin{array}{l}\text { Stone } \\
\text { localization }\end{array}$} & Lower pole & $16(34.8 \%)$ & $9(18.4 \%)$ & \\
\hline & Middle pole & $20(43.5 \%)$ & $9(18.4 \%)$ & \\
\hline & Upper pole & $1(2.2 \%)$ & $1(2.0 \%)$ & \\
\hline & Ureteropelvic junction & $5(10.9 \%)$ & $10(20.4 \%)$ & \\
\hline \multicolumn{2}{|c|}{ Stone size $(\mathrm{mm})($ Mean $\pm \mathrm{SD})$} & $16.3 \pm 7.5$ & $11.0 \pm 4.0$ & ${ }^{\mathrm{c}}<0.001^{*}$ \\
\hline \multicolumn{2}{|c|}{ Pre-op GFR $\left(\mathrm{mL} / \mathrm{min} / 1.73 \mathrm{~m}^{2}\right)($ Mean $\pm \mathrm{SD})$} & $76.6 \pm 18.7$ & $74.9 \pm 17.7$ & ${ }^{\mathrm{a}} 0.64$ \\
\hline \multicolumn{2}{|c|}{ Post-op $1^{\text {st }}$ day GFR $\left(\mathrm{mL} / \mathrm{min} / 1.73 \mathrm{~m}^{2}\right)($ Mean $\pm \mathrm{SD})$} & $76.9 \pm 18.9$ & $80.5 \pm 17.5$ & ${ }^{\mathrm{a}} 0.33$ \\
\hline \multicolumn{2}{|c|}{ Post-op $1^{\text {st }}$ month GFR $\left(\mathrm{mL} / \mathrm{min} / 1.73 \mathrm{~m}^{2}\right)($ Mean $\pm \mathrm{SD})$} & $75.2 \pm 17.6$ & $82.6 \pm 17.8$ & ${ }^{\mathrm{a}} 0.06$ \\
\hline \multicolumn{2}{|c|}{ Early GFR change $\left(\mathrm{mL} / \mathrm{min} / 1.73 \mathrm{~m}^{2}\right)($ Mean $\pm \mathrm{SD})$} & $0.37 \pm 13.5$ & $5.65 \pm 12.5$ & ${ }^{\circ} 0.04^{*}$ \\
\hline \multicolumn{2}{|c|}{ Late GFR change $\left(\mathrm{mL} / \mathrm{min} / 1.73 \mathrm{~m}^{2}\right)($ Mean $\pm \mathrm{SD})$} & $-2.40 \pm 14.1$ & $7.75 \pm 11.8$ & ${ }^{c}<0.001^{*}$ \\
\hline
\end{tabular}

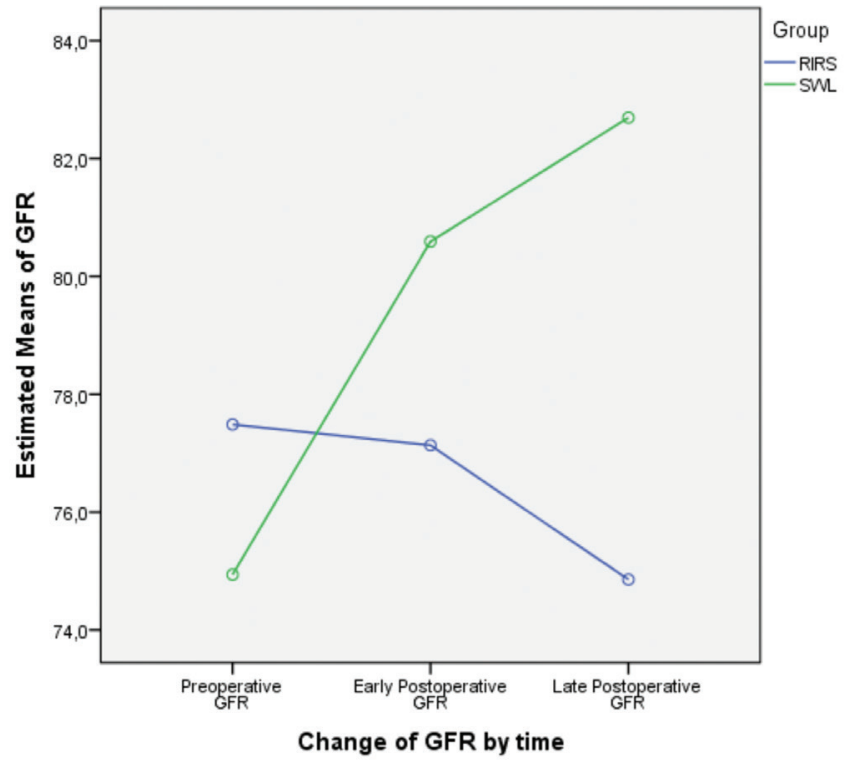

Figure 1. Relationship of changing glomerular filtration rate by the time between groups

SWL: Schok wave lithoripsy, GFR: Glomerular filtration rate

difference in other variables between subgroups ( $p>0.05$ for all)

(Table 2). Upper pole kidney stones ( $n=1$ vs $n=1)$, multiple kidney stones ( $n=3$ vs $n=0)$ and ureter stones ( $n=1$ vs $n=20)$ could not be compared because of insufficient number of patients. When the groups were compared according to obstructing stones (all the stones in the ureter and ureteropelvic junction) there was no statistically significant difference in changes in GFR in the early and late postoperative period ( $p>0.05$ for both).

When the patients with stones smaller than $20 \mathrm{~mm}$ in diameter in the RIRS and SWL groups were compared, no significant difference was observed in GFR changes in the early postoperative period between the groups ( $p>0.05)$. In contrast, there was a statistically significant increase in GFR in the late postoperative period in patients with a stone less than $20 \mathrm{~mm}$ in diameter $(p=0.001)$. When the patients with stones larger than $20 \mathrm{~mm}$ in diameter in the RIRS and SWL groups were compared there was no difference in GFR changes in the early and late postoperative periods ( $p>0.05$ for both).

\section{Discussion}

In the present study, we calculated the changes in GFR in the early postoperative and late postoperative periods. The study results showed statistically significant differences between RIRS and SWL groups. We assume that the differences in change in GFR values were mostly due to more invasive nature of RIRS compared to SWL. Tubular function may be compromised 


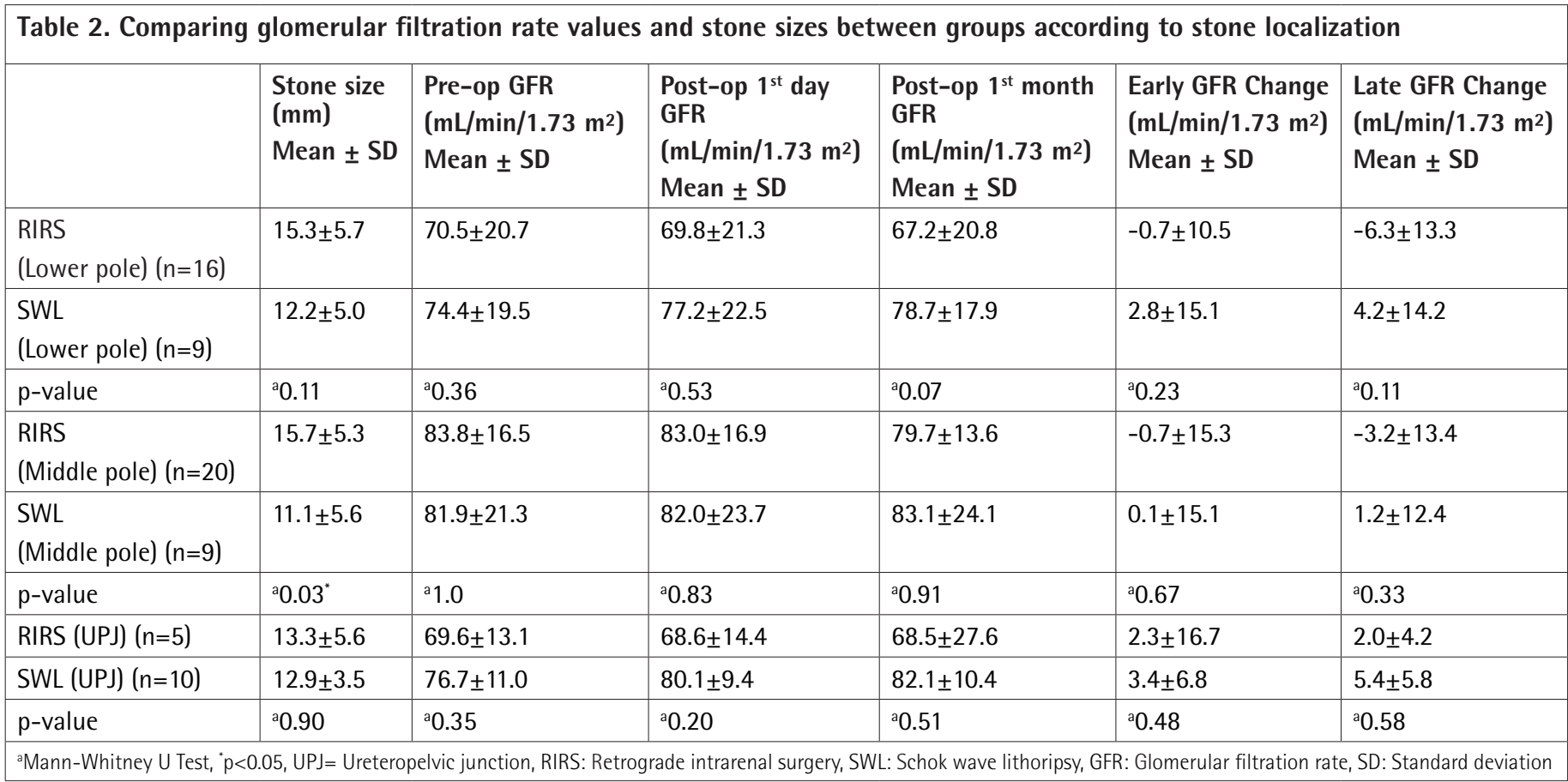

by an acute increase in the intrarenal pressure. Interstitial fibrosis and loss of nephrons due to interstitial inflammation and renal tubular cell apoptosis may result in impairment of renal functions (14). Stone disease is a common urological entity that is managed with different surgical or nonsurgical approaches. The method of management depends on the size and location of the stone $(9,15,16)$. Minimally-invasive treatment methods are the latest trend in stone surgery with the advances in endourologic technology. Several studies have been conducted in order to compare these operational and nonoperational methods $(2,9)$. PCNL seems to be the most effective and successful treatment modality especially for stones greater than $20 \mathrm{~mm}$ in diameter but it is the most invasive method, therefore, the surgeon must consider less invasive methods such as SWL and RIRS (17). Invasive procedures may pose a risk of injury to kidneys. There have been studies comparing SWL and $\operatorname{RIRS}(2,7,9)$. SWL is a less invasive treatment modality compared to RIRS, however, RIRS seems to have higher success and lower re-treatment rates (18). All these interventions affect the renal function and there are fewer studies evaluating and comparing these aspects $(10,19,20)$.

According to our knowledge, there is no study comparing the renal functional outcomes after RIRS and SWL. In our study, decreased GFR values after RIRS procedure in the late period may be due to increased intrarenal pressure during operation and irritation of the ureteropelvicalicial system by the surgical instrument. In this context, more increase in GFR levels after the treatment of ureteral stones than other stones also shows the importance of obstruction of the urinary tract for kidney functions. These changes showed that SWL had more positive effects on GFR when compared to RIRS especially for stones with a diameter of less than $20 \mathrm{~mm}$.

Success of these two procedures depends on the fragmentation of stones and urinary drainage of the fragmented stones. Appropriate drainage prevents obstructive effects and the mechanism of increase in GFR values. On the other hand, both of them may cause a minimal decline in renal function. During $S W L$, shock wave energy may damage the renal parenchyma and during RIRS procedure, fluid infusions may result in an increase in intrarenal pressure and these conditions may cause renal damage $(11,19)$. However, a few reports evaluating long-term outcomes of SWL treatment in patients with chronic renal failure also suggest that SWL is a safe treatment modality $(21,22)$. In their animal model of metabolic syndrome, Handa et al. (20) reported that a single session of SWL did not result in renal impairment, even in the presence of metabolic syndrome. As a result of the first study in the literature investigating the effect of RIRS on renal functions, univariate cox regression analysis revealed that multiple procedures and pre-existing chronic kidney disease were significant factors for renal deterioration (19). However, in multivariate analysis these factors did not remain as predictive factors; researchers declared that RIRS seemed to have favorable outcomes on kidney function (19). Similarly, when we evaluated the GFR changes over time with general linear model, SWL was found to be a favorable method for renal function. However, we did not find positive effect of RIRS procedure on renal functions. In this study, the comparison of changes in GFR levels indicated the importance of considering SWL as first line treatment when compared to RIRS especially 
for stones with a diameter of less than $20 \mathrm{~mm}$, independently of stone location.

\section{Study Limitations}

Nonetheless, this study has some limitations. First of all, it has a retrospective design with a relatively small sample size and the inherent retrospective and non-randomized nature may have led to selection bias. Secondly, stone sizes were larger in RIRS group; prolonged operative time may lead to more decreased level of renal functions. Finally, obstructive stones percentage was higher in SWL group. It is known that renal functions improve following removal of obstructive stones. However, in our study cohort, we did not find any differences in early and late GFR changes in patients with obstructive stones between the groups. This may be due to the small number of patients with obstructive stones in the RIRS group.

\section{Conclusion}

RIRS is associated with less improved GFR in comparison with SWL. SWL should be considered as first-line treatment for kidney and ureteral stones considering the changes in GFR values comparing to RIRS especially for stones with a diameter of less than $20 \mathrm{~mm}$. A greater difference was observed in changes in GFR values in the late postoperative period, however, further large-scale randomised studies are warranted to support these results.

\section{Ethics}

Ethics Committee Approval: University of Health Sciences Gülhane Ethics Committee for non-interventional research (protocol no: 2019/393).

Informed Consent: Written informed consent was obtained from each patient

Peer-review: Internally peer-reviewed.

\section{Authorship Contributions}

Concept: S.S., C.S., T.E., Design: S.S., C.S., T.E., Data Collection or Processing: N.K., E.K., Analysis or Interpretation: S.S., S.B., T.Ö., Ö.F.K., Literature Search: S.S., N.K., C.S., T.E., Writing: S.S., N.K.

Conflict of Interest: No conflict of interest was declared by the authors.

Financial Disclosure: The authors declared that this study received no financial support.

\section{References}

1. Donaldson $J F$, Lardas $M$, Scrimgeour $D$, Stewart $F$, MacLennan $S$, Lam TB, McClinton S. Systematic review and meta-analysis of the clinical effectiveness of shock wave lithotripsy, retrograde intrarenal surgery, and percutaneous nephrolithotomy for lower-pole renal stones. Eur Urol 2015;67:612-616.

2. Srisubat A, Potisat $S$, Lojanapiwat $B$, Setthawong $V$, Laopaiboon $M$. Extracorporeal shock wave lithotripsy (ESWL) versus percutaneous nephrolithotomy (PCNL) or retrograde intrarenal surgery (RIRS) for kidney stones. Cochrane Database Syst Rev 2014;CD007044.

3. Portis AJ, Sundaram CP. Diagnosis and initial management of kidney stones. Am Fam Physician 2001;63:1329-1338.

4. Ercil H, Alma E, Bas O, Sener NC, Vuruskan E, Kuyucu F, Unal U, Goren MR, Evliyaoglu Y. Treatment of Moderate Sized Renal Pelvis Calculi: Stone Clearance Time Comparison of Extracorporeal Shock Wave Lithotripsy and Retrograde Intrarenal Surgery. Urol J 2016;13:2490-2495.

5. Ergin G, Kirac M, Kopru B, Ebiloglu T, Kibar Y, Biri H. Shock wave lithotripsy or retrograde intrarenal surgery: which one is more effective for $10-20-\mathrm{mm}$ renal stones in children. Ir J Med Sci 2018;187:1121-1126.

6. Gokce MI, Tokatli Z, Suer E, Hajiyev P, Akinci A, Esen B. Comparison of shock wave lithotripsy (SWL) and retrograde intrarenal surgery (RIRS) for treatment of stone disease in horseshoe kidney patients. Int Braz J Urol 2016;42:96-100

7. Javanmard B, Kashi AH, Mazloomfard MM, Ansari Jafari A, Arefanian S. Retrograde Intrarenal Surgery Versus Shock Wave Lithotripsy for Renal Stones Smaller Than 2 cm: A Randomized Clinical Trial. Urol J 2016;13:28232828.

8. Chaussy C, Brendel W, Schmiedt E. Extracorporeally induced destruction of kidney stones by shock waves. Lancet 1980;2:1265-1268.

9. Zheng $\mathrm{C}$, Yang $\mathrm{H}$, Luo J, Xiong B, Wang $\mathrm{H}$, Jiang $\mathrm{O}$. Extracorporeal shock wave lithotripsy versus retrograde intrarenal surgery for treatment for renal stones 1-2 cm: a meta-analysis. Urolithiasis 2015;43:549-556.

10. Wood K, Keys T, Mufarrij P, Assimos DG. Impact of stone removal on renal function: a review. Rev Urol 2011;13:73-89.

11. Evan AP, Willis LR. Extracorporeal shock wave lithotripsy: complications. In: Smith AD, et al., eds. Smith's Textbook on Endourology. Hamilton: BC Decker, Inc., 2007, pp. 353-365.

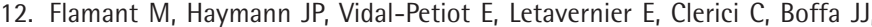
Vrtovsnik F. GFR estimation using the Cockcroft-Gault, MDRD study, and CKD-EPI equations in the elderly. Am J Kidney Dis 2012;60:847-849.

13. Levey AS, Coresh J, Greene T, Stevens LA, Zhang YL, Hendriksen S, Kusek JW, Van Lente F; Chronic Kidney Disease Epidemiology C. Using standardized serum creatinine values in the modification of diet in renal disease study equation for estimating glomerular filtration rate. Ann Intern Med 2006;145:247-254.

14. Hamdi A, Hajage D, Van Glabeke E, Belenfant X, Vincent F, Gonzalez F, Ciroldi M, Obadia E, Chelha R, Pallot JL, Das V. Severe post-renal acute kidney injury, post-obstructive diuresis and renal recovery. BJU Int 2012;110:E1027-1034.

15. Kumar A, Kumar N, Vasudeva $P$, Kumar Jha $S$, Kumar R, Singh H. A prospective, randomized comparison of shock wave lithotripsy, retrograde intrarenal surgery and miniperc for treatment of 1 to $2 \mathrm{~cm}$ radiolucent lower calyceal renal calculi: a single center experience. J Urol 2015;193:160-164.

16. Singh BP, Prakash J, Sankhwar SN, Dhakad U, Sankhwar PL, Goel A, Kumar $M$. Retrograde intrarenal surgery vs extracorporeal shock wave lithotripsy for intermediate size inferior pole calculi: a prospective assessment of objective and subjective outcomes. Urology 2014;83:1016-1022.

17. Ozturk U, Sener NC, Goktug HN, Nalbant I, Gucuk A, Imamoglu MA. Comparison of percutaneous nephrolithotomy, shock wave lithotripsy, and retrograde intrarenal surgery for lower pole renal calculi 10-20 mm. Urol Int 2013;91:345-349 
18. Rojas A, Gallegos H, Salvado JA. [Shock wave lithotripsy, retrograde intrarenal surgery or percutaneous nephrolithotomy for lower pole renal stones?]. Medwave 2015;15:e6254.

19. Hoarau N, Martin F, Lebdai S, Chautard D, Culty T, Azzouzi AR, Bigot P. Impact of retrograde flexible ureteroscopy and intracorporeal lithotripsy on kidney functional outcomes. Int Braz J Urol 2015;41:920-926.

20. Handa RK, Johnson CD, Connors BA, Evan AP, Phillips CL, Liu Z. Shock wave lithotripsy does not impair renal function in a Swine model of metabolic syndrome. J Endourol 2015;29:468-473.
21. Chandhoke PS, Albala DM, Clayman RV. Long-term comparison of renal function in patients with solitary kidneys and/or moderate renal insufficiency undergoing extracorporeal shock wave lithotripsy or percutaneous nephrolithotomy. J Urol 1992;147:1226-1230.

22. Yoo DE, Han SH, Oh HJ, Kim SJ, Shin DH, Lee MJ, Yoo TH, Kang SW, Choi $\mathrm{KH}$. Removal of kidney stones by extracorporeal shock wave lithotripsy is associated with delayed progression of chronic kidney disease. Yonsei Med J 2012;53:708-714. 